\title{
Tolerance of Selected Orange and Mandarin Hybrid Fruit to Low-dose Irradiation for Quarantine Purposes
}

\author{
W.R. Miller, R.E. McDonald, and J. Chaparro \\ U.S. Department of Agriculture, Agricultural Research Service, United \\ States Horticultural Research Laboratory, 2001 South Rock Road, Fort \\ Pierce, FL 34945 \\ Additional index words. postharvest, quality, radiation, Citrus sinensis, C. reticulata
}

\begin{abstract}
Tolerance of many citrus cultivars to low-dose irradiation treatment is not known. Ten citrus cultivars grown in Florida, including the five orange [Citrus sinensis ( $L$.) Osbeck] cultivars, Ambersweet, Hamlin, Navel, Pineapple, and Valencia, and the five mandarin hybrids (Citrus reticulata Blanco), 'Fallglo', 'Minneola', 'Murcott', 'Sunburst', and 'Temple', were exposed to irradiation at $0,0.15,0.3$, and $0.45 \mathrm{kGy}$, and stored for 14 days at $1^{\circ} \mathrm{C}$ or $5^{\circ} \mathrm{C}$ plus 3 days at $20^{\circ} \mathrm{C}$, to determine dose tolerance based on fruit injury. Softening of 'Valencia', 'Minneola', 'Murcott', and 'Temple' was dose-dependent, but that of other cultivars was unaffected. Only 'Ambersweet', 'Valencia', 'Minneola', and 'Murcott' did not develop peel pitting at $0.15 \mathrm{kGy}$ or higher. Total soluble solids of 'Ambersweet' and 'Sunburst' declined slightly with increasing dose. Titratable acidity (TA) of oranges was not affected, but TA of 'Sunburst' and 'Temple' juice was slightly reduced by irradiation at $0.45 \mathrm{kGy}$. Juice flavor of 'Hamlin', 'Navel', 'Valencia', and 'Minneola', and pulp flavor of 'Hamlin', 'Valencia', 'Fallglo', 'Minneola', and 'Murcott' was less acceptable after irradiation at 0.3 or $0.45 \mathrm{kGy}$. The appearance of all cultivars was negatively affected by the loss of glossiness with the $0.45 \mathrm{kGy}$ dose. Less than $1.0 \%$ of fruit decayed and irradiation treatment had no effect on decay. Our study indicates that growers and shippers need to be aware that the effects of irradiation on citrus fruits are highly variable and both cultivar-dependent and dose-dependent.
\end{abstract}

During the 1960s, there was considerable interest in determining the efficacy of ionizing radiation as a means to control organisms causing rot of fresh fruits and vegetables. Most of these studies exposed fruit, including citrus cultivars, to relatively high doses $(>1.0$ $\mathrm{kGy}$ ) of irradiation. Bramlage and Couey (1965) found that growth of Penicillium digitatum [(Pers: Fr.) Sacc.] was retarded by a dose of $1.0 \mathrm{kGy}$, and rot development was prevented by $1.5 \mathrm{kGy}$ in 'Washington Navel' oranges, but only when fruit were irradiated immediately after inoculation. However, moderate peel pitting developed at doses $>0.5$ kGy. Grierson and Dennison (1965) exposed 'Valencia' oranges and 'Marsh' grapefruit to $1.5,3.0$, and $4.5 \mathrm{kGy}$, and found that neither Diplodia natalensis [Pole-Evans] nor Penicillium $s p$. was controlled, and that both fruits developed peel pitting after 1 week of storage at $20{ }^{\circ} \mathrm{C}$ following irradiation at all doses. Dennison et al. (1966) irradiated 'Duncan'

\footnotetext{
Received for publication 1 Nov. 1999. Accepted for publication 18 Feb. 2000. Mention of a trademark, warranty, proprietary product, or vendor does not constitute a guarantee by the U.S. Dept. of Agriculture (USDA), and does not imply its approval to the exclusion of other products or vendors that may also be suitable. We thank V. Chew, C.C. Carroll, and M. Kesinger for supplying some of the plant material used in this study. The cost of publishing this paper was defrayed in part by the payment of page charges. Under postal regulations, this paper therefore must be hereby marked advertisement solely to indicate this fact.
}

treatment for quarantine purposes and found that the fruit would tolerate dosages up to $0.75 \mathrm{kGy}$. The negative effects of irradiation included loss of aroma, flavor, and pulp texture, but not peel injury. O'Mahony et al. (1985) evaluated California-grown 'Navel' oranges following irradiation at 0.6 to 0.8 kGy; peel blemishes were observed after 5 to 6 weeks of storage. Mitchell et al. (1991) found that the juice of 'Valencia' oranges irradiated at 0.75 or $3.0 \mathrm{kGy}$ was acceptable.

Control of quarantine pests has been the reason for much of the irradiation research on fresh fruits and vegetables since the mid1980s. Hallman (1999) surveyed the current state of commercial irradiation and established its importance as a viable alternative to methyl bromide fumigation for quarantine treatment of fruit flies. The development of disease causing organisms generally could not be controlled even with irradiation doses higher than $1.0 \mathrm{kGy}$, but doses of $0.225 \mathrm{kGy}$ or less needed for sterilization of most fruit fly larvae, and many of the pests were controlled at $<1.0 \mathrm{kGy}$. These lower doses caused less damage to fresh fruits and vegetables. Currently, a $1.0 \mathrm{kGy}$ maximum absorbed dose is allowed for use on fresh fruits and vegetables (Federal Register, 1986). The proposed USDA policy for application of irradiation as a quarantine treatment against major fruit flies is outlined in the Federal Register (1996).

Thresholds of tolerance to irradiation injury for specific orange or mandarin cultivars grown in Florida are not available, but this information is required for irradiation of citrus for quarantine purposes. The purpose of this study was to determine the physical or physiological tolerance of 10 commercial orange and mandarin cultivars grown in Florida to low-dose irradiation.

\section{Materials and Methods}

dependent on the degree of initial peel color (fruit maturity) and on storage temperature (Ahmed et al., 1966). California-grown 'Washington Navel' and 'Valencia' oranges tolerated irradiation doses to $2.0 \mathrm{kGy}$ without injury or any decline in organoleptic properties (Maxie et al., 1969). Irradiation-induced injury on 'Shamouti' oranges was more severe in immature than in mature fruit (Monselise and Kahan, 1966). Riov et al. (1968) demonstrated immediate and sustained increases in phenylalanine ammonia-lyase activity after irradiation $(2.0 \mathrm{kGy})$ of 'Shamouti' oranges and 'Marsh' grapefruit, which could have contributed to peel pitting. Riov (1975) observed accumulation of phenolic compounds in damaged flavedo cells shortly after exposure to irradiation $(2.4 \mathrm{kGy}$, at $1.55 \mathrm{kGy}$ ), resulting in cell death and peel pitting. Belli-Donini et al. (1974) irradiated 'Valencia', 'Ovale', and 'Tarocco' oranges and showed that various accumulated terpene compounds diffused into the damaged exocarp cells and caused peel damage, suggesting that the natural resistance to peel damage was cultivar-dependent. Nagai and Moy (1985) shipped California-grown 'Valencia' oranges to Hawaii for irradiation
Five orange cultivars, Ambersweet, Hamlin, Navel, Pineapple, and Valencia, and five mandarin hybrids, Fallglo, Minneola, Murcott, Sunburst, and Temple, were either: 1) harvested three times at 1-week intervals; or 2) obtained from a single harvest directly from a packinghouse (within $24 \mathrm{~h}$ of harvest) prior production seasons. Fruit harvested at 1-week intervals were replicated over harvests. Fruit obtained from a packinghouse were replicated over three lots. All fruit were taken to the U.S. Horticultural Research Laboratory in Orlando and washed, waxed (590 HG; FMC Corp., Lakeland, Fla.), and randomly sorted into three replicates (cartons) for each of four irradiation doses. Fruit numbers of each cultivar differed, as fruit size varied by cultivar, and fruit were packed into three, 14.1-L (0.4 bu) commercial fiberboard citrus cartons (Table 1). Within $24 \mathrm{~h}$ of harvest, fruit were irradiated at FTS, Mulberry, Fla. using $\mathrm{Co}^{60}$, and the absorbed dose was monitored with Gammachrome YR dosimeters (range 0.1-0.3 kGy) Harwell Laboratory, Oxfordshire, UK (Table 2). Irradiation was applied at a rate of $0.14 \mathrm{kGy} \cdot \mathrm{min}^{-1}$ and to processing, during the 1997-98 or 1998-99 
Table 1. Citrus cultivars, harvest dates, fruit size, fruit per carton, and storage temperatures following irradiation.

\begin{tabular}{lccccc}
\hline \hline Cultivar & Type/hybrid & $\begin{array}{c}\text { Harvest } \\
\text { date }\end{array}$ & $\begin{array}{c}\text { Mean fruit } \\
\text { diam. }(\mathrm{mm})\end{array}$ & $\begin{array}{c}\text { No. fruit } \\
\text { per box }\end{array}$ & $\begin{array}{c}\text { Storage } \\
\text { temp. }\left({ }^{\circ} \mathrm{C}\right)\end{array}$ \\
\hline Ambersweet & Sweet orange (SO) & Nov. 1997 & 81.1 & 45 & 1 \\
Hamlin & Sweet orange & Dec. 1998 & 67.1 & 40 & 1 \\
Navel & Sweet orange & Dec. 1998 & 80.6 & 30 & 1 \\
Pineapple & Sweet orange & Feb. 1999 & 75.2 & 36 & 1 \\
Valencia & Sweet orange & June 1998 & 70.7 & 36 & 1 \\
Fallglo & Bower x Temple & Nov. 1998 & 76.5 & 38 & 5 \\
Minneola & Duncan x Dancy & Feb. 1999 & 76.5 & 30 & 5 \\
Murcott & Tangerine X SO & Mar. 1999 & 75.4 & 50 & 1 \\
Sunburst & Robinson X Osceola & Dec. 1997 & 74.1 & 45 & 5 \\
Temple & Tangerine X SO & Mar. 1999 & 77.1 & 45 & 5 \\
\hline
\end{tabular}

doses were targeted at $0,0.15,0.3$, and 0.45 $\mathrm{kGy}$. However, the actual mean absorbed dosages over all fruit irradiated at the three levels were $0,0.19,0.4$, and $0.58 \mathrm{kGy}$, respectively (Table 2). Dosimeters were placed at the center and edges of the fruit mass in each carton to insure that the center fruit received the minimum dose. Consequently, the mean absorbed dose was higher then the target dose, but the range of absorbed dose within targeted dose categories was relatively low. Following irradiation, all fruit were returned to the Orlando Laboratory for cold storage and evaluation. Before storage, 20 fruit in each carton were randomly marked and placed for $14 \mathrm{~d}$ at either 1 or $5^{\circ} \mathrm{C}$, depending on USDA recommendations (Hardenburg et al., 1986), plus $3 \mathrm{~d}$ at $20{ }^{\circ} \mathrm{C}$, and then evaluated. At the end of storage, fruit firmness, weight loss, total soluble solids (TSS), titratable acidity (TA), juice color, juice flavor, and pulp flavor were determined. Firmness was determined using an Instron Food Texture instrument (model 4411; Instron, Canton, Mass.) using an 11-mm cylinder penetrating $5 \mathrm{~mm}$ at $25 \mathrm{~cm} \cdot \mathrm{min}^{-1}$ per fruit. Mean fresh weight loss was determined on a per fruit basis. The TSS and TA were measured using standard procedures. Color of a composite 14fruit juice aliquot per carton was determined using a Minolta chromameter (model CR 300, with CR A20 apparatus; Minolta Camera Co., Osaka, Japan) in the $\mathrm{X}, \mathrm{y}, \mathrm{x}$ color mode. Tristimulus measurements were automatically integrated by the Minolta chromameter into commercial color numbers used for juice grading purposes. The higher the color value, the more commercially acceptable the juice. Juice and pulp flavor were subjectively determined on a composite sample of fruit per treatment by a seven-member untrained panel scoring on a hedonic scale ranging from 0 (extremely unacceptable) to 100 (extremely acceptable). In addition, peel pitting, fruit aging, peel appearance, and incidence of decay were rated by two experienced persons. Peel pitting was scored on each fruit as $1=$ no pitting, $2=$ slight, $3=$ moderate, $4=$ fairly severe, and $5=$ severe, based on $0,<10 \%, 10 \%$ to $25 \%, 26 \%$ to $50 \%$, and $>50 \%$, respectively, of peel surface area affected.

Peel aging symptoms, which are usually observed as concentric areas of necrotic tissue at the stem end, were rated on each fruit as $1=$ slight (not circumventing stem scar), $2=$ moderate (circumventing stem scar), and 3 $=$ severe (circumventing stem scar and extend- ing $5 \mathrm{~mm}$ outward) based on the amount of relative surface area affected. Peel appearance was determined by the degree of blemish-free surface area, good color, and surface gloss observed and rated as $1=$ good, 2 = fair, and 3 $=$ poor (color naturally bright, fairly bright, or dull, respectively). Incidence of decay was determined on a fruit number basis.

A randomized complete-block experimental design was used. Means were subjected to analysis of variance (ANOVA) procedures and Duncan's multiple range test $(P \leq 0.05)$ was used to determine significant differences in means for attribute values among the four irradiation doses for each citrus cultivar.

\section{Results}

Fruit firmness. The 0.3 and $0.45 \mathrm{kGy}$ doses resulted in softer 'Valencia' orange fruit than did 0 and $0.15 \mathrm{kGy}$ treatments (Table 3 ). 'Murcott' and 'Temple' mandarins subjected to $0.45 \mathrm{kGy}$, and 'Minneola' receiving 0.3 $\mathrm{kGy}$, were softer than fruit from other doses (Table 4).

Peel pitting. Irradiation at all levels caused peel pitting in 'Hamlin' and 'Navel' oranges (Table 3). Only 'Ambersweet' (1.3\%) and 'Valencia' (1.5\%) had sufficiently low peel pitting to be commercially acceptable. 'Minneola' and 'Murcott' fruit were not affected by irradiation up to $0.45 \mathrm{kGy}$. Peel pitting occurred at all irradiation doses on 'Fallglo', 'Sunburst', and 'Temple' fruit (Table 4).

Weight loss. Irradiation did not affect weight loss of any orange cultivar with the exception of 'Navel' treated at $0.15 \mathrm{kGy}$ (Table 3). All radiation doses increased weight loss in 'Sunburst' and 'Temple' fruit, and $0.15 \mathrm{kGy}$ increased the loss in 'Murcott' fruit (Table 4).

Total soluble solids and titratable acidity. Irradiation did not affect TSS or TA of orange cultivars, with the exception of a decrease in TSS in 'Ambersweet' at a dose of $0.3 \mathrm{kGy}$ (Table 3). A dose of $0.45 \mathrm{kGy}$ reduced TSS of 'Sunburst' mandarin and TA of both 'Sunburst' and 'Tangelo', and $0.3 \mathrm{kGy}$ increased TA of 'Murcott' (Table 4).

Juice color. Juice color of oranges (Table 3) and mandarins (Table 4) was not affected by irradiation at any dose.

Juice and fruit flavor. Acceptability of juice flavor of 'Hamlin' and 'Navel' oranges and 'Minneola' mandarin was reduced by irradiation at $0.45 \mathrm{kGy}$, while that of 'Valencia'
Table 2. Irradiation absorbed doses for various citrus fruit cultivars.

\begin{tabular}{|c|c|c|c|}
\hline \multirow[b]{2}{*}{ Cultivar $^{2}$} & \multicolumn{3}{|c|}{ Target doses (kGy) } \\
\hline & 0.15 & 0.30 & 0.45 \\
\hline & \multicolumn{3}{|c|}{ Actual doses $(\mathrm{kGy})^{\mathrm{y}}$} \\
\hline Ambersweet & 0.19 & 0.39 & 0.61 \\
\hline Hamlin & 0.19 & 0.40 & 0.56 \\
\hline Navel & 0.19 & 0.40 & 0.56 \\
\hline Pineapple & 0.19 & 0.41 & 0.56 \\
\hline Valencia & 0.18 & 0.38 & 0.60 \\
\hline Fallglo & 0.19 & 0.41 & 0.58 \\
\hline Minneola & 0.19 & 0.43 & 0.59 \\
\hline Murcott & 0.20 & 0.41 & 0.61 \\
\hline Sunburst & 0.19 & 0.39 & 0.61 \\
\hline Temple & 0.15 & 0.36 & 0.51 \\
\hline Mean & 0.19 & 0.40 & 0.58 \\
\hline Range & $0.15-0.20$ & $0.36-0.41$ & $0.51-0.61$ \\
\hline
\end{tabular}

${ }^{2}$ Dose means for 'Minneola', 'Temple', and 'Murcott' calculated from nine individual cartons of fruit of one harvest. Dose means of other cultivars were calculated from three harvests of three cartons each for a total of nine cartons of fruit.

${ }^{\mathrm{y}}$ Dose rate was $0.14 \mathrm{kGy} \cdot \mathrm{min}^{-1}$ for all fruit.

was reduced at all doses. Pulp flavor of 'Hamlin' and 'Valencia' orange and of 'Fallglo', 'Minneola', and 'Murcott' mandarin was negatively affected at $0.45 \mathrm{kGy}$ (Table 3). Acceptability was also reduced at $0.15 \mathrm{kGy}$ for 'Fallglo', and at $0.3 \mathrm{kGy}$ for 'Murcott' mandarin.

Peel aging, general external appearance, and decay. Symptoms of aging developed on $8 \%$ and $4 \%$ of 'Ambersweet' and 'Valencia' oranges, respectively, and on $8 \%$ of 'Fallglo' mandarin, but irradiation had no significant effect on aging (data not shown). Less than $1.0 \%$ of other cultivars were affected by aging. The external appearance of all cultivars was significantly reduced by irradiation mainly because of loss of surface gloss, especially at $0.45 \mathrm{kGy}$. Decay incidence was not affected by irradiation treatment, and the mean percentage of decay was $<1 \%$ for all cultivars.

\section{Discussion}

Tolerance of the various orange and mandarin cultivars to low-dose irradiation varied widely, especially in effects on peel pitting and flavor. Peel pitting was the major indicator of irradiation stress in these fruits. Fresh fruit showing peel lesions or discoloration are not acceptable for fresh market sales. The minimum dose required for quarantine treatment against Caribbean fruit fly (Aanstrepha suspensa (Loew) larva is 0.15 kGy. 'Ambersweet', 'Valencia', 'Minneola', and 'Murcott' showed good pitting tolerance to irradiation at the highest absorbed dosage applied in this study (mean $0.58 \mathrm{kGy}$ ), but 'Hamlin', 'Navel', 'Pineapple', 'Fallglo', 'Sunburst', and 'Temple' were not sufficiently tolerant for fresh market sales, even at the minimum absorbed dose of $0.15 \mathrm{kGy}$. The reason for less pitting of 'Temple' fruit at the highest than at lower doses is not known. Based on the percentage of fruit with symptoms of peel pitting, 'Sunburst', 'Fallglo', and 'Temple' were not tolerant of irradiation 
Table 3. Fruit quality characteristics of oranges after irradiation at $0,0.15,0.3$, or $0.45 \mathrm{kGy}$ and storage for $14 \mathrm{~d}$ at various cool storage temperatures (See Table 1) and $3 \mathrm{~d}$ at $20^{\circ} \mathrm{C}$.

\begin{tabular}{lccccccccc}
\hline \hline Cultivar & $\begin{array}{c}\text { Dose } \\
\text { kGy }\end{array}$ & $\begin{array}{c}\text { Firmness } \\
(\mathrm{N})\end{array}$ & $\begin{array}{c}\text { Peel pitting } \\
(\%)\end{array}$ & $\begin{array}{c}\text { Wt loss } \\
(\%)\end{array}$ & $\begin{array}{c}\text { TSS } \\
(\%)\end{array}$ & $\begin{array}{c}\text { TA } \\
(\%)\end{array}$ & $\begin{array}{c}\text { Juice color } \\
\text { value }^{\mathrm{z}}\end{array}$ & $\begin{array}{c}\text { Juice flavor } \\
\text { index }^{\mathrm{y}}\end{array}$ & $\begin{array}{c}\text { Pulp flavor } \\
\text { index }\end{array}$ \\
\hline Ambersweet & 0.00 & 34.0 & $0.0 \mathrm{a}$ & $2.3 \mathrm{a}$ & $11.2 \mathrm{a}$ & $0.70 \mathrm{a}$ & $37.7 \mathrm{a}$ & $84 \mathrm{a}$ & $77 \mathrm{a}$ \\
& 0.15 & 37.9 & $0.0 \mathrm{a}$ & $1.3 \mathrm{a}$ & $10.8 \mathrm{ab}$ & $0.68 \mathrm{a}$ & $37.6 \mathrm{a}$ & $82 \mathrm{a}$ & $74 \mathrm{a}$ \\
& 0.30 & 34.6 & $2.2 \mathrm{a}$ & $2.0 \mathrm{a}$ & $10.7 \mathrm{~b}$ & $0.68 \mathrm{a}$ & $37.6 \mathrm{a}$ & $82 \mathrm{a}$ & $79 \mathrm{a}$ \\
\multirow{5}{*}{ Hamlin } & 0.45 & 36.6 & $2.7 \mathrm{a}$ & $2.1 \mathrm{a}$ & $10.8 \mathrm{ab}$ & $0.71 \mathrm{a}$ & $37.5 \mathrm{a}$ & $80 \mathrm{a}$ & $79 \mathrm{a}$ \\
& 0.00 & 24.4 & $0.0 \mathrm{~b}$ & $3.2 \mathrm{a}$ & $10.9 \mathrm{a}$ & $1.35 \mathrm{a}$ & $35.1 \mathrm{a}$ & $80 \mathrm{a}$ & $84 \mathrm{a}$ \\
& 0.15 & 25.4 & $38.9 \mathrm{a}$ & $2.7 \mathrm{a}$ & $11.6 \mathrm{a}$ & $0.73 \mathrm{a}$ & $35.2 \mathrm{a}$ & $76 \mathrm{ab}$ & $78 \mathrm{ab}$ \\
& 0.30 & 24.3 & $32.2 \mathrm{a}$ & $2.7 \mathrm{a}$ & $11.5 \mathrm{a}$ & $0.74 \mathrm{a}$ & $35.3 \mathrm{a}$ & $78 \mathrm{a}$ & $79 \mathrm{ab}$ \\
Navel & 0.45 & 22.8 & $46.7 \mathrm{a}$ & $2.9 \mathrm{a}$ & $11.5 \mathrm{a}$ & $0.71 \mathrm{a}$ & $35.3 \mathrm{a}$ & $71 \mathrm{~b}$ & $73 \mathrm{~b}$ \\
& 0.00 & 29.8 & $0.0 \mathrm{~b}$ & $1.8 \mathrm{~b}$ & $10.7 \mathrm{a}$ & $0.64 \mathrm{a}$ & $36.1 \mathrm{a}$ & $83 \mathrm{a}$ & $80 \mathrm{a}$ \\
& 0.15 & 29.8 & $42.8 \mathrm{a}$ & $2.1 \mathrm{a}$ & $10.7 \mathrm{a}$ & $0.57 \mathrm{a}$ & $36.1 \mathrm{a}$ & $79 \mathrm{ab}$ & $79 \mathrm{a}$ \\
& 0.30 & 28.9 & $28.9 \mathrm{a}$ & $1.8 \mathrm{~b}$ & $10.6 \mathrm{a}$ & $0.60 \mathrm{a}$ & $36.1 \mathrm{a}$ & $77 \mathrm{ab}$ & $78 \mathrm{a}$ \\
Pineapple & 0.45 & 26.6 & $40.6 \mathrm{a}$ & $1.9 \mathrm{ab}$ & $10.5 \mathrm{a}$ & $0.62 \mathrm{a}$ & $36.2 \mathrm{a}$ & $73 \mathrm{~b}$ & $73 \mathrm{a}$ \\
& 0.00 & 32.4 & $0.0 \mathrm{~b}$ & $1.8 \mathrm{a}$ & $12.7 \mathrm{a}$ & $0.77 \mathrm{a}$ & $37.6 \mathrm{a}$ & $79 \mathrm{a}$ & $77 \mathrm{a}$ \\
& 0.15 & 30.6 & $11.7 \mathrm{a}$ & $2.0 \mathrm{a}$ & $12.6 \mathrm{a}$ & $0.85 \mathrm{a}$ & $37.6 \mathrm{a}$ & $76 \mathrm{a}$ & $69 \mathrm{a}$ \\
& 0.30 & 29.8 & $11.1 \mathrm{a}$ & $2.0 \mathrm{a}$ & $12.6 \mathrm{a}$ & $0.84 \mathrm{a}$ & $37.6 \mathrm{a}$ & $76 \mathrm{a}$ & $75 \mathrm{a}$ \\
Valencia & 0.45 & 29.5 & $11.7 \mathrm{a}$ & $2.0 \mathrm{a}$ & $12.3 \mathrm{a}$ & $0.78 \mathrm{a}$ & $37.6 \mathrm{a}$ & $75 \mathrm{a}$ & $65 \mathrm{a}$ \\
& 0.00 & 36.4 & $0.6 \mathrm{a}$ & $2.4 \mathrm{a}$ & $11.1 \mathrm{a}$ & $0.99 \mathrm{a}$ & $40.5 \mathrm{a}$ & $85 \mathrm{a}$ & $85 \mathrm{a}$ \\
& 0.15 & 35.0 & $2.8 \mathrm{a}$ & $2.6 \mathrm{a}$ & $11.2 \mathrm{a}$ & $1.01 \mathrm{a}$ & $40.9 \mathrm{a}$ & $80 \mathrm{~b}$ & $84 \mathrm{a}$ \\
& 0.30 & 33.1 & $0.6 \mathrm{a}$ & $2.5 \mathrm{a}$ & $10.0 \mathrm{a}$ & $0.97 \mathrm{a}$ & $40.9 \mathrm{a}$ & $78 \mathrm{bc}$ & $77 \mathrm{ab}$ \\
& 0.45 & 32.2 & $2.2 \mathrm{a}$ & $2.6 \mathrm{a}$ & $10.7 \mathrm{a}$ & $1.00 \mathrm{a}$ & $40.3 \mathrm{a}$ & $75 \mathrm{c}$ & $72 \mathrm{~b}$ \\
\hline
\end{tabular}

${ }^{2}$ Determined by chromameter. The higher the value, the more commercially acceptable the juice.

${ }^{y}$ Subjectively determined by an untrained seven-member panel on a hedonic scale from 1 (extremely unacceptable) to 100 ( extremely acceptable).

${ }^{x}$ Mean separation within cultivars by Duncan's multiple range test, at $P \leq 0.05$.

Table 4. Fruit quality characteristics of mandarins after irradiation at $0.0,0.15,0.3$, or $0.45 \mathrm{kGy}$ and storage for $14 \mathrm{~d}$ at various cool temperatures (See Table 1) and $3 \mathrm{~d}$ at $20^{\circ} \mathrm{C}$.

\begin{tabular}{|c|c|c|c|c|c|c|c|c|c|}
\hline Cultivar & $\begin{array}{l}\text { Dose } \\
\text { kGy }\end{array}$ & $\begin{array}{c}\text { Firmness } \\
(\mathrm{N})\end{array}$ & $\begin{array}{c}\text { Peel pitting } \\
(\%)\end{array}$ & $\begin{array}{c}\text { Wt loss } \\
(\%)\end{array}$ & $\begin{array}{l}\text { TSS } \\
(\%)\end{array}$ & $\begin{array}{l}\text { TA } \\
(\%)\end{array}$ & $\begin{array}{c}\text { Juice color } \\
\text { value }^{z}\end{array}$ & $\begin{array}{c}\text { Juice flavor } \\
\text { index }^{\mathrm{y}}\end{array}$ & $\begin{array}{l}\text { Pulp flavor } \\
\text { index }\end{array}$ \\
\hline \multirow[t]{4}{*}{ Fallglo } & 0.00 & $18.7 \mathrm{a}^{\mathrm{x}}$ & $0.6 \mathrm{c}$ & $3.1 \mathrm{a}$ & $10.3 \mathrm{a}$ & $1.92 \mathrm{a}$ & $42.6 \mathrm{a}$ & $76 \mathrm{a}$ & $72 \mathrm{a}$ \\
\hline & 0.15 & $18.0 \mathrm{a}$ & $13.3 \mathrm{bc}$ & $3.1 \mathrm{a}$ & $10.3 \mathrm{a}$ & $1.05 \mathrm{a}$ & $42.5 \mathrm{a}$ & $71 \mathrm{a}$ & $62 \mathrm{bc}$ \\
\hline & 0.30 & $18.5 \mathrm{a}$ & $25.0 \mathrm{~b}$ & $3.1 \mathrm{a}$ & $10.2 \mathrm{a}$ & $1.92 \mathrm{a}$ & $42.6 \mathrm{a}$ & $65 \mathrm{a}$ & $67 \mathrm{ab}$ \\
\hline & 0.45 & $18.6 \mathrm{a}$ & $53.3 \mathrm{a}$ & $3.2 \mathrm{a}$ & $10.2 \mathrm{a}$ & $1.05 \mathrm{a}$ & $42.5 \mathrm{a}$ & $62 \mathrm{a}$ & $59 \mathrm{c}$ \\
\hline \multirow[t]{4}{*}{ Mineola } & 0.00 & $22.5 \mathrm{a}$ & $0.0 \mathrm{a}$ & $1.6 \mathrm{a}$ & $13.3 \mathrm{a}$ & $0.78 \mathrm{a}$ & $40.5 \mathrm{a}$ & $80 \mathrm{a}$ & $60 \mathrm{a}$ \\
\hline & 0.15 & $20.6 \mathrm{ab}$ & $0.0 \mathrm{a}$ & $2.6 \mathrm{a}$ & $13.1 \mathrm{a}$ & $0.74 \mathrm{a}$ & $40.2 \mathrm{a}$ & $78 \mathrm{a}$ & $56 \mathrm{a}$ \\
\hline & 0.30 & $19.8 \mathrm{~b}$ & $1.7 \mathrm{a}$ & $2.0 \mathrm{a}$ & $12.9 \mathrm{a}$ & $0.75 \mathrm{a}$ & $40.3 \mathrm{a}$ & $77 \mathrm{ab}$ & $57 \mathrm{a}$ \\
\hline & 0.45 & $21.7 \mathrm{ab}$ & $1.7 \mathrm{a}$ & $2.5 \mathrm{a}$ & $12.9 \mathrm{a}$ & $0.77 \mathrm{a}$ & $40.3 \mathrm{a}$ & $72 \mathrm{~b}$ & $46 \mathrm{~b}$ \\
\hline \multirow[t]{4}{*}{ Murcott } & 0.00 & $20.6 \mathrm{a}$ & $0.0 \mathrm{a}$ & $3.0 \mathrm{~b}$ & $13.0 \mathrm{a}$ & $0.78 \mathrm{~b}$ & $46.3 \mathrm{a}$ & $83 \mathrm{a}$ & $81 \mathrm{a}$ \\
\hline & 0.15 & $19.0 \mathrm{ab}$ & $1.1 \mathrm{a}$ & $3.6 \mathrm{a}$ & $12.9 \mathrm{a}$ & $0.80 \mathrm{ab}$ & $46.6 \mathrm{a}$ & $77 \mathrm{a}$ & $76 \mathrm{ab}$ \\
\hline & 0.30 & $19.8 \mathrm{ab}$ & $1.1 \mathrm{a}$ & $2.8 \mathrm{~b}$ & $13.0 \mathrm{a}$ & $0.82 \mathrm{a}$ & $46.5 \mathrm{a}$ & $81 \mathrm{a}$ & $71 \mathrm{~b}$ \\
\hline & 0.45 & $17.3 \mathrm{~b}$ & $1.1 \mathrm{a}$ & $3.1 \mathrm{ab}$ & $13.0 \mathrm{a}$ & $0.80 \mathrm{ab}$ & $46.5 \mathrm{a}$ & $82 \mathrm{a}$ & $71 \mathrm{~b}$ \\
\hline \multirow[t]{4}{*}{ Sunburst } & 0.00 & $18.4 \mathrm{a}$ & $0.0 \mathrm{~b}$ & $2.7 \mathrm{~b}$ & $11.8 \mathrm{a}$ & $1.10 \mathrm{a}$ & $41.8 \mathrm{a}$ & $71 \mathrm{a}$ & $69 \mathrm{a}$ \\
\hline & 0.15 & $18.7 \mathrm{a}$ & $99.4 \mathrm{a}$ & $3.5 \mathrm{a}$ & $11.7 \mathrm{ab}$ & $1.00 \mathrm{a}$ & $41.8 \mathrm{a}$ & $62 \mathrm{a}$ & $68 \mathrm{a}$ \\
\hline & 0.30 & $17.9 \mathrm{a}$ & $100.0 \mathrm{a}$ & $3.7 \mathrm{a}$ & $11.6 \mathrm{ab}$ & $1.00 \mathrm{a}$ & $41.9 \mathrm{a}$ & $66 \mathrm{a}$ & $65 \mathrm{a}$ \\
\hline & 0.45 & $16.8 \mathrm{a}$ & $100.0 \mathrm{a}$ & $4.0 \mathrm{a}$ & $11.3 \mathrm{~b}$ & $0.97 \mathrm{~b}$ & $41.8 \mathrm{a}$ & $65 \mathrm{a}$ & $63 \mathrm{a}$ \\
\hline \multirow[t]{4}{*}{ Temple } & 0.00 & $14.4 \mathrm{a}$ & $0.0 \mathrm{c}$ & $2.6 \mathrm{~b}$ & $12.2 \mathrm{a}$ & $0.87 \mathrm{a}$ & $39.7 \mathrm{a}$ & $89 a$ & $69 a$ \\
\hline & 0.15 & $14.2 \mathrm{a}$ & $5.6 \mathrm{bc}$ & $3.2 \mathrm{a}$ & $12.1 \mathrm{a}$ & $0.86 \mathrm{a}$ & $39.4 \mathrm{a}$ & $89 a$ & $70 \mathrm{a}$ \\
\hline & 0.30 & $14.2 \mathrm{a}$ & $32.8 \mathrm{a}$ & $3.1 \mathrm{a}$ & $12.0 \mathrm{a}$ & $0.87 \mathrm{a}$ & $39.4 \mathrm{a}$ & $86 \mathrm{a}$ & $70 \mathrm{a}$ \\
\hline & 0.45 & $12.7 \mathrm{~b}$ & $19.4 \mathrm{ab}$ & $3.4 \mathrm{a}$ & $11.9 \mathrm{a}$ & $0.80 \mathrm{~b}$ & $39.5 \mathrm{a}$ & $85 \mathrm{a}$ & $64 \mathrm{a}$ \\
\hline
\end{tabular}

${ }^{2}$ Determined by chromameter. The higher the value, the more commercially acceptable the juice.

${ }^{y}$ Subjectively determined by an untrained seven-member panel on a hedonic scale from 1 (extremely unacceptable) to 100 ( extremely acceptable).

${ }^{x}$ Mean separation within cultivars by Duncan's multiple range test, at $P \leq 0.05$.

at $0.3 \mathrm{kGy}$, and 'Sunburst' was the least tolerant of all cultivars evaluated. The navel orange in our study was a Florida selection ('Nucellar Navel'), which apparently does not tolerate irradiation treatment as well as the 'Washington Navel' grown in California (Guerrero et al., 1967; Maxie et al., 1969). Fruit used by Maxie et al. (1969) was harvested in California, but was not irradiated in Hawaii until $8 \mathrm{~d}$ later. The delay in treatment may have contributed to the resistance of the fruit to peel pitting at $1.0 \mathrm{kGy}$. Bramlage and Couey (1965) found that 'Washington $\mathrm{Na}$ vel' seriously pitted at $0.5 \mathrm{kGy}$, which is more comparable with our results. However, 'Valencia' oranges grown in Florida were as tolerant to irradiation stress as those grown in California (Nagai and Moy, 1985).

Another main indicator of quality of irradiated fruit is juice or pulp flavor. Juice flavor of 'Hamlin', 'Navel', and 'Valencia' and pulp flavor of 'Hamlin' and 'Valencia' oranges was reduced at the highest absorbed dose. The juice flavor of 'Minneola' and pulp flavor of 'Fallglo', 'Minneola', and 'Murcott' mandarins were the least acceptable at the highest dosage. The TA was slightly reduced in 'Sunburst' and 'Temple' at $0.45 \mathrm{kGy}$, but acceptability of juice or pulp flavor was not affected.

In conclusion, the tolerance of fresh citrus fruits irradiated for quarantine or other purposes is cultivar-dependent. Minimum and maximum irradiation doses for quarantine treatment for fruit fly larvae may injure some citrus cultivars. If irradiation becomes the treatment of choice by citrus fruit growers/ shippers in the future, further research on the use of a heat treatment prior to irradiation may be warranted for those cultivars that will not tolerate required irradiation doses (Miller and McDonald, 1998).

\section{Literature Cited}

Ahmed, E. M., F.W. Knapp, and R.A. Dennison. 1966. Changes in peel color during storage of irradiated oranges. Proc. Florida State Hort. Soc. 79:296-301.

Belli-Donini, M.L., D. Baraldi, and R. Taggi. 1974. 
Relationship between peel damage and the accumulation of terpene compounds in irradiated oranges. Rad. Bot. 14:1-9.

Bramlage, W.J. and H.M. Couey. 1965. Gamma radiation of fruit to extend market life. Agr. Res. Ser., U.S. Dept. of Agriculture Market. Res. Rpt. No. 717.

Dennison, R.A., W. Grierson, and E.M. Ahmed. 1966. Irradiation of Duncan grapefruit, Pineapple and Valencia oranges and Temples. Proc. Florida State Hort. Soc. 79:285-292.

Federal Register. 1986. Irradiation in the production, processing, and handling of food. Final rule. Vol. 56(75):13375-13399 (18 Apr.). U.S Govt. Printing Office, Washington, D.C.

Federal Register. 1996. The application of irradiation to phytosanitary problems. Vol. 61 (95): 24433-24439 (15 May). U.S. Govt. Printing Office, Washington, D.C.

Grierson, W. and R.A. Dennison. 1965. Radiation treatment of 'Valencia' oranges and 'Marsh' grapefruit. Proc. Florida State Hort. Soc. 78:233-237.
Guerrero, F.P., E.C. Maxie, C.F. Johnson, I.L. Eaks, and N.F. Sommer. 1967. Effects of postharvest gamma irradiation on orange fruits. Proc. Amer. Soc. Hort. Sci. 90:515-528.

Hallman, G.J. 1999. Ionizing radiation quarantine treatments against tephritid fruit flies. Postharvest Biol. Technol. 16:93-106.

Hardenburg, R.E., A.E. Watada, and C.Y. Wang. 1986. The commercial storage of fruits, vegetables, and florist and nursery stocks. Agr. Hdbk. 66. U.S. Dept. Agriculture, Agr. Res. Serv.

Maxie, E.E., M.F. Sommer, and I.L. Eaks. 1969. Effect of gamma radiation on citrus fruits, $\mathrm{p}$. 1375-87. In: Proc. First Intl. Citrus Symp., Vol. 3, 16-26 Mar. 1968. Riverside, Calif., Univ. of California Press.

Miller, W.R. and R.E. McDonald. 1998. Shortterm heat conditioning of grapefruit to alleviate irradiation injury. HortScience 33:12241227.

Mitchell, F.E., A.R. Isaacs, D.J. Williams, R.L McLauchlan, S.M. Nottingham, and K.
Hammerton. 1991. Low dose irradiation influence on yield and quality of fruit juice. J. Food Sci. 56:1628-1631.

Monselise, S.P. and R.S. Kahan. 1966. Changes in composition and in enzymatic activities of flavedo and juice of Shamouti oranges following gamma radiation. Rad. Bot. 6:265-274.

Nagai, N.Y. and J.H. Moy. 1985. Quality of gamma irradiated California Valencia oranges. J. Food Sci. 50:215-219.

O'Mahony, M., S.Y. Wong, and N. Odbert. 1985. Sensory evaluation of Navel oranges treated with low doses of gamma-radiation. J. Food Sci. 50:639-646.

Riov, J. 1975. Histochemical evidence for the relationship between peel damage and the accumulation of phenolic compounds in gammairradiated citrus fruit. Rad. Bot. 15:257-260.

Riov, J., S.P. Monselise, and R.S. Kahan. 1968. Effect of gamma radiation on phenylalanine ammonialyase activity and accumulation of phenolic compounds in citrus fruit peel. Rad. Bot. 8:463-466. 